\title{
T16 - Comparación de curvas regionales y métodos de precipitación escorrentía para la estimación de avenidas máximas
}

\author{
Priscilla Riggioni \\ Programa de Posgrado en Ciencias de la Atmósfera, Universidad de Costa Rica
}

*Autor al que se dirige la correspondencia: decanato@sep.ucr.ac.cr

\section{Resumen}

U no de los parámetros más importantes a la hora de escoger y dimensionar una obra hidráulica, indistintamente del tamaño de cuenca, es el caudal de diseño. Este dato se encuentra dentro de la cuantificación de eventos extremos que realizan los profesionales en hidrología. En micro cuencas donde generalmente no existe ningún tipo de registro, se recurre a modelos de precipitación-escorrentía tradicionales o empíricos, para la estimación de este valor. Con estos modelos se pueden obtener estimaciones erróneas de caudales, al sobreestimar la dimensión de las estructuras o, en el peor de los casos, subestimarlas. La magnitud óptima del caudal de diseño es la que posee un balance entre la seguridad de la obra (riesgos asociados) y su costo. El presente trabajo de investigación realizó un análisis comparativo de caudales de crecientes asociados a períodos de retorno menores a 500 años para estructuras hidráulicas de pequeño tamaño, ubicadas en micro cuencas sin registros hidrológicos. Para lo anterior, se compararon estimaciones de caudal realizadas entre curvas regionales elaboradas para Costa Rica, contra tres métodos empíricos: método racional, envolventes de Creager y método SCS; para una cuenca piloto en la vertiente Caribe. La comparación de resultados entre distintas metodologías de cálculo mostró una alta dependencia de la calidad de la base de datos y una marcada diferencia entre métodos empíricos y estadísticos. Se llegaron a resultados y conclusiones importantes para micro cuencas, donde los registros de caudal son no confiables o inexistentes.

Palabras claves: Histología, análisis regional, avenidas máximas, obras hidráulicas, riesgo

\begin{abstract}
$\mathrm{O}$ ne of the most important parameters in the selection and dimensioning of hydraulic structures, no matter the size of the basin, is the flow design. This hydraulic parameter is found in the quantification of extreme events made by hydrology professionals. In small basins, where there is no information, traditional precipitation-runoff models or empirical models, are used. With these type of models, the design flow can be over estimate or sub estimate, affecting the design dimensions of the structures. The optimal magnitude of the design flow, permits a balance between security of the structure (associated risks) and its cost. This investigation show a comparative analysis of peak flows associated to return periods of less than 500 years for small hydraulic structures, located in small basins without hydraulic information. For this work, flow predictions between regional curves were estimated for Costa Rica, and compared with three empirical methods: Rational, Creager envelope curves and Soil Conservation Service Method. These was done for a study basin in the Caribbean Region. Comparison of results between the methods studied, show high dependence in the quality of the data base information and significant discharge results between the empirical methods and the statistical methods. Important results and conclusions for small basins were found in areas where discharge registries are unreliable or are inexistent.
\end{abstract}

Keywords: Hydrology, regional analysis, maximum flood, hydraulic structures, risk sobre protección a los derechos de autor, con criterio especificados en la licencia Creative Commons (CC BY-NC-SA 4.0) 